\title{
The Influence of Sociodemographic
} Factors on the Use of

\section{Antihypertensive Drugs Among Adults in Serbia: Cross-Sectional Study}

\author{
Nataša M. Mihailović ${ }^{1}$, Snežana M. Radovanovićc, ${ }^{2,3}$, Dragan V. Vasiljevićc ${ }^{4,5}$, \\ Nela Ž. Donović, ${ }^{4,5}$, Svetlana R. Radević ${ }^{3}$, Mihajlo B. Jakovljević ${ }^{6}$ \\ ${ }^{1}$ Department of Biostatistics, The Institute of Public Health Kragujevac, Kragujevac, Serbia \\ ${ }^{2}$ Department of Social medicine, The Institute of Public Health Kragujevac, Kragujevac, Serbia \\ ${ }^{3}$ Social Medicine, The Faculty of Medical Sciences University of Kragujevac, Kragujevac, Serbia \\ ${ }^{4}$ Department of Hygiene and Human Ecology, The Institute of Public Health Kragujevac, \\ Kragujevac, Serbia \\ ${ }^{5}$ Hygiene and Human Ecology, The Faculty of Medical Sciences University of Kragujevac, \\ Kragujevac, Serbia \\ ${ }^{6}$ Health Economics and Pharmacoeconomics, The Faculty of Medical Sciences, University of \\ Kragujevac, Serbia
}

\section{SUMMARY}

Background: Despite the knowledge that they have high blood pressure, which can be controlled with medicines, one portion of the patients still ignores doctor's advice. The aim of the research was to examine the impact of socio-demographic factors for treatment of hypertension among adults in Serbia.

Subjects and methods: In the study, we used data from the National Health Survey of the Republic of Serbia in 2013. The sample consisted of respondents who had diagnosed hypertension, 5073 of them. The dependent variable in the study was binary (treatment, or no treatment of hypertension) and independent was socio-demographic characteristics of respondents. Logistic regression was used to determine sociodemographic predictors associated with blood pressure control.

Results: From a total of 5073 diagnosed hypertensive patients, $91.3 \%$ of them cures high blood pressure. Women, older, medium rich patients, those who follow health topics on television and those who do not follow them on the Internet, who, in the past year, have been hospitalized or used the services of daily care significantly more often treat hypertension.

The results of binary logistic regression in which the dependent variable is the treatment of high blood pressure, showed that a statistically significantly predictors are: age, gender, the wealth index and monitoring topics related to health through television and the Internet. In the treatment of hypertension, the strongest predictor was the index of well-being. Thus, people who are medium rich are almost three times more likely to treat high blood pressure compared to the richest $(O R=2.94$, $95 \% \mathrm{Cl}=1.54-5.59)$. A statistically significant difference in treatment is not recorded 
between the richest and the poorest ( $p>0.05)$. Men are 1.5 times more likely to treat their tension as compared to women $(\mathrm{OR}=1.54,95 \% \mathrm{Cl}=1.02-2.32)$. People following itopics related to the health via the internet are1.7 times more likely to treat hypertension in comparison to subjects who do not follow these topics via the Internet $(\mathrm{OR}=1.72,95 \% \mathrm{Cl}=1.07-2.76)$.

Conclusion: Analysis of the impact of sociodemographic characteristics on the awareness of patients about the importance of treatment of hypertension is an important step in defining the strategies for treatment of patients.

Keywords: hypertension, antihypertensive treatment, sociodemographic factors

\section{INTRODUCTION}

Hypertension is a major global health problem [1]. Studies show that, although today there is a whole spectrum of effective antihypertensive drugs, the number of patients who keep their pressure under control is small [2]. If untreated, hypertension poses the risk of developing coronary heart disease, heart failure, stroke and sudden death $[3,4]$.

In Serbia, noncommunicable chronic diseases are the leading cause of illness and death of people, and the rate of death from diseases of high blood pressure is growing from year to year. In 2015, the percentage share of hypertension in the structure of dying from heart disease and blood vessels amounted to $11.1 \%$ [5].

The analysis of the impact of sociodemographic factors in the treatment of hypertension is the first step in understanding the reason for the absence of treatment of hypertension in the adult population in the Republic of Serbia.

\section{THE AIM OF THE RESEARCH}

To examine the impact of socio-demographic factors and use of health care services for treatment of hypertension among adults in Serbia.

\section{SUBJECTS AND METHODS}

In the study, we used data from the National Health Survey of the Republic of Serbia in 2013 [6]. The type ofthe sample is nationally representative, stratified by type of two-sample, without repetition, whose size is determined based on the recommendations of the European Commission [7]. Stratification implies a geographical division of the territory of the Republic of Serbia on four main strata: Vojvodina, Belgrade, Šumadija and Western Serbia, Southern and Eastern Serbia. Each stratum is divided into urban and rural areas. The twophase sampling involves local communities, as the units of the first stage, i.e. the household as a unit of the second stage.

From basic set (14623 respondents) a sample for analysis was isolated. The sample consisted of respondents who had diagnosed hypertension, 5073 of them.

The dependent variable in the study was binary (Do you treat your hypertension or not), and independent was socio-demographic characteristics of respondents.

\section{Statistical analysis}

Data are described by using descriptive statistical methods, and analyzed by the method for the analysis of differences ( $\chi^{2}$ test and $t$-test), that is, by the regression model (binary logistic regression). Regarding the descriptive statistical methods, percentages were used as indicators of the structure and the mean value as thearithmetic average and standard deviation as a measure of variability.

Testing the significance of differences of categorical variables was conducted by using Chi-Square test, and a continuous one by using Student's $t$ test. Impact analysis of predictors for treatment of hypertension was performed by using binary, logistic regression. In the results listed below, there are probabilities (p) and a the values $\mathrm{p} \leq 0,05$ were considered as significant ones. All data were analyzed in SPSS (Statistical Package for the Social Sciences) 19.0 program.

\section{RESULTS}

In Serbia, every third respondent has hypertension (34.8\%). With the years the percentage of hypertensive patients in the population increases, reaching a peak in the age group of 55-64 years (Figure 1). From a total of $5073 \mathrm{di}-$ 


\begin{tabular}{|c|c|c|c|c|}
\hline \multirow{2}{*}{ Variables } & \multirow{2}{*}{ Categories } & \multicolumn{2}{|c|}{ Treating hypertension } & \multirow{2}{*}{$\mathbf{p}$} \\
\hline & & Yes $(n, \%)$ & No $(n, \%)$ & \\
\hline \multicolumn{2}{|l|}{ Age } & $62.39 \pm 12.23$ & $50.54 \pm 14.95$ & $<0.001$ \\
\hline \multirow{2}{*}{ Gender } & Male & $397(86.3)$ & $63(13.7)$ & \multirow{2}{*}{$<0.001$} \\
\hline & Female & $908(92.7)$ & $72(7.3)$ & \\
\hline \multirow{3}{*}{ Education } & Elementary School & $483(91.3)$ & $46(8.7)$ & \multirow{3}{*}{$>0.05$} \\
\hline & Secondary School & $622(90.5)$ & $65(9.5)$ & \\
\hline & Post secondary School & $200(89.3)$ & $24(10.7)$ & \\
\hline \multirow{3}{*}{ The wealth index } & The poorest & $266(87.2)$ & $39(12.8)$ & \multirow{3}{*}{$<0.05$} \\
\hline & Middle & $840(92.6)$ & $243(7.4)$ & \\
\hline & The wealthiest & $199(87.3)$ & $67(12.7)$ & \\
\hline \multirow{4}{*}{ Region } & Vojvodina & $293(88)$ & $40(12)$ & \multirow{4}{*}{$>0.05$} \\
\hline & Beograd & $316(90)$ & $35(10)$ & \\
\hline & Šumadija and West Serbia & $322(92.5)$ & $26(7.5)$ & \\
\hline & South and East Serbia & $374(91.7)$ & $34(8.3)$ & \\
\hline \multirow{2}{*}{ Type of settlement } & City & $771(90.6)$ & $80(9.4)$ & \multirow{2}{*}{$>0.05$} \\
\hline & Other & $534(90.7)$ & $55(9.3)$ & \\
\hline \multirow{2}{*}{ Employment Status } & Employed & $235(80.2)$ & $58(19.8)$ & \multirow{2}{*}{$<0.001$} \\
\hline & Unemployed & $1070(93.3)$ & $77(6.7)$ & \\
\hline \multirow{2}{*}{ Marital status } & Married & $874(90.3)$ & $94(9.7)$ & \multirow{2}{*}{$>0.05$} \\
\hline & Unmarried & $431(91.3)$ & $41(8.7)$ & \\
\hline \multicolumn{5}{|c|}{ Do you follow healthtopics on } \\
\hline \multirow{2}{*}{ Television } & Yes & 1139 (91.9) & $101(8.1)$ & \multirow{2}{*}{$<0.001$} \\
\hline & No & $156(83)$ & $32(17)$ & \\
\hline \multirow{2}{*}{ Radio } & Yes & $327(90.1)$ & $36(9.9)$ & \multirow{2}{*}{$>0.05$} \\
\hline & No & $968(91)$ & $96(9)$ & \\
\hline \multirow{2}{*}{ Newspapers } & Yes & $675(91)$ & $67(9)$ & \multirow{2}{*}{$>0.05$} \\
\hline & No & $619(90.5)$ & $65(9.5)$ & \\
\hline Internet & Yes & $244(82,4)$ & $52(17.67)$ & $<0001$ \\
\hline internet & No & $1046(92.9)$ & $80(7.1)$ & \\
\hline Hornitalizotion & Yes & $185(95.4)$ & $9(4.6)$ & $\cap 001$ \\
\hline Hospitatızation & No & $1120(89.9)$ & $126(10.1)$ & $<0.001$ \\
\hline Dailv hospital & Yes & $232(94.7)$ & $13(5.3)$ & $<0.05$ \\
\hline & No & $1073(89.8)$ & $122(10.2)$ & \\
\hline Inability to purchase med & ines for & & & \\
\hline Financial reasons & Yes & $239(90.5)$ & $25(9.5)$ & $>0.05$ \\
\hline & No & $994(92.5)$ & $81(7.5)$ & \\
\hline & Very good & $19(73.1)$ & $7(26.9)$ & \\
\hline & Good & $226(81.9)$ & $50(18.1)$ & \\
\hline Self-assessment of health & Neither bad nor good & $616(92.2)$ & $52(7.8)$ & $<0.001$ \\
\hline & Bad & $361(94.3)$ & $22(5.7)$ & \\
\hline & Very bad & $81(96.4)$ & $3(3.6)$ & \\
\hline
\end{tabular}

Table 1. Influence of socio-demographic factors and the use of hospital care in the treatment of hypertension agnosed hypertensive patients, $91.3 \%$ of them cures high blood pressure in one of three possible ways: diet, medication or a combination. The most ardent patients when it comes to the treatment of hypertension patients are aged
55-64 years, where over $90 \%$ of them take the antihypertensives prescribed by their doctor. In addition, $28.4 \%$ of subjects in the course of the previous two weeks voluntarily used any medication or a plant treatment products from 
Figure 1. The frequency of patients who have high blood pressure by age groups

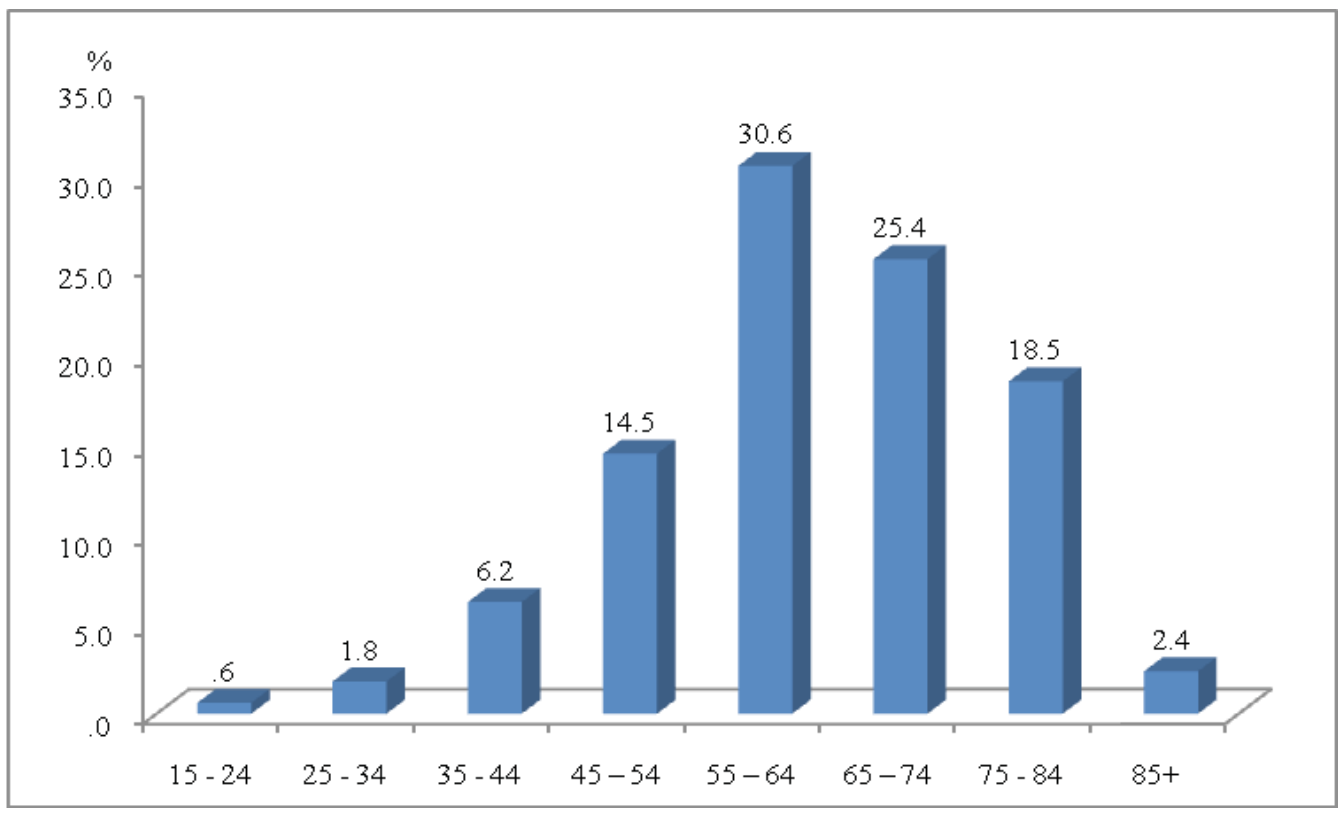

the group of over-the-counter drugs.

Patients who treat their hypertension are, on average, 7 years older than patients who are not treated $(\mathrm{p}<0.001)$. A statistically significant difference in the treatment of high blood pressure is recorded compared to the gender as well $(\mathrm{p}<0.001)$. Specifically, $92.7 \%$ of women and $86.3 \%$ men treat their blood pressure. Medium rich patients, those who follow health topics on television and those who do not follow them on the Internet, who, in the past year, have been hospitalized or used the services of daily care significantly more often treat hypertension. Every fourth respondent assessed their health as very good, although they did not treat their blood pressure and almost all respondents who are treated, assessed their health in the same way (96.4\%).

When it comes to the treatment of hypertension, the education of the subjects, marital status, the region where they live, type of the place where they live, the way they are tracking topics related to health, via the press and radio, as well as the inability to purchase the medicine, for financial reasons - do not influence it.

The results of binary logistic regression in which the dependent variable is the treatment of high blood pressure, showed that a statistically significantly predictors are: age, gender, the wealth index and monitoring topics related to health through television and the Internet. In the treatment of hypertension, the strongest predictor was the index of well-be- ing. Thus, people who are medium rich almost are almost three times more likely to treat high blood pressure compared to the richest, where all other factors in the model are not changed. A statistically significant difference in treatment is not recorded between the richest and the poorest ( $p>0.05)$. Men are 1.5 times more likely to treat their tension as compared to women. People following itopics related to the health on television are 0.6 times less likely, while those who follow these topics via the internet are1.7 times more likely to treat hypertension by altering their diet, with medication, or a combination of the two, in comparison to subjects who do not follow these topics via the

\section{DISCUSSION}

Thanks to the national research, it is possible to consider not only the the scope of patients who follow the recommendations for the treatment of hypertension, but defining the predictor for the treatment of hypertension for certain population groups in relation to their socio-demographic characteristics as well.

Hypertension and diabetes mellitus type 2 bear significant financial burden for healthcare system of Serbia [8].In period 20042012.public spending increased by statins and novel platelet aggregation inhibitors [9].Similary, in Republic of Srpska value of prescriptions drugs agents acting on the renin-angiotensin system reported growth in period the Internet (Table 2). 


\begin{tabular}{|c|c|c|c|}
\hline Independent variables & Categories & OR $(95 \% \mathrm{Cl})$ & p \\
\hline Age & & $0.95(0.93-0.97)$ & $<0.001$ \\
\hline \multirow{2}{*}{ Gender } & Male & 1 & \\
\hline & Female & $1.54(1.02-2.32)$ & $<0.05$ \\
\hline \multirow{3}{*}{ The wealth index } & The wealthiest & 1 & \multirow{3}{*}{$<0.05$} \\
\hline & Middle & $2.94(1.54-5.59)$ & \\
\hline & The poorest & $>0.05$ & \\
\hline \multirow{2}{*}{ Employment Status } & Unemployed & \multirow{2}{*}{$>0.05$} & \\
\hline & Employed & & \\
\hline \multicolumn{4}{|c|}{ Do you follow healthtopics on } \\
\hline \multirow{2}{*}{ Television } & Yes & \multicolumn{2}{|l|}{1} \\
\hline & No & $0.60(0.36-0.99)$ & $<0.05$ \\
\hline \multirow{2}{*}{ Internet } & Yes & \multicolumn{2}{|l|}{1} \\
\hline & No & $1.72(1.07-2.76)$ & $<0.05$ \\
\hline \multirow{2}{*}{ Hospitalization } & Yes & \multirow{2}{*}{$>0.05$} & \\
\hline & No & & \\
\hline \multirow{2}{*}{ Daily hospital } & Yes & \multirow{2}{*}{$>0.05$} & \\
\hline & No & & \\
\hline \multirow{5}{*}{ Self-assessment of health } & Very bad & \multirow{5}{*}{$>0.05$} & \\
\hline & Very good & & \\
\hline & Good & & \\
\hline & Average & & \\
\hline & Bad & & \\
\hline
\end{tabular}

Table 2. Socio-demographic factors and the use of hospital care as predictors in the treatment of hypertension
2009-2013 [10].

Despite the efforts that are being invested for past several decades about raising awareness about the importance of treatment of hypertension, studies around the world show that the gap between the knowledge of the actual values of tension and desired ones still exists, and that only one-third of adults are aware of their state of health and the importance of treatment of their health $[11,12]$. In our research, one in ten patients never treated their high blood-pressure, which is less, compared to the research conducted in other European as well as African countries [13,14]. Although hypertension should be treated as soon as it is discovered, regardless of the age of the patient, the findings indicate that with age the number of patients who treat their hypertension increases as well, what some authors associated with comorbidities [15]. According to them, morbid conditions such as: diabetes mellitus, rheumatic disease or kidney disease, which is most common in elderly people, force patients to initiate treatment as the underlying cause of disease and comorbidity, bur hypertension does not force them to do the same [16]. Gender differences in appearance, height, but also in relation to the treatment of high blood pressure are known from earlier. Namely, the men, as it is considered, under the influence of sex hormones have higher blood pressure compared to women, but lower awareness about it [17-19]. About $8 \%$ of all pregnancies are complicated with hypertensive disorders [20]. Similarly to previous researches, the type of settlement had no impact on the treatment of pressure [21]. Unlike our findings in which pressure control is not related to education degrees, in others, with the higher level of education of patients, the control was also higher [22].

\section{CONCLUSION}

Even though hypertension is a condition which, compared to any other cardiovascular disease, has the largest number of approved drugs and medicines and most of them can be purchased with a prescription at the pharmacy, the percentage of untreated patients is still high.Analysis of the impact of sociodemographic characteristics on the awareness of patients about the importance of treatment of hypertension is an important step in defining 
the strategies for treatment of patients.

\section{REFERENCES}

1. Shrivastava SR, Shrivastava PS and Ramasamy J. The Determinants and Scope of Public Health Interventions to Tackle the Global Problem of Hypertension.Int J Prev Med. 2014; 5(7): 807-812.

2. Menanga A, Edie S, Nkoke C, Boombhi J, Musa AJ, Mfeukeu LK, et al. Factors associated with blood pressure control amongst adults with hypertension in Yaounde, Cameroon: a cross-sectional study. CardiovascDiagnTher. 2016; 6(5): 439-445.

3. EkunYesyo OJ, Allman RM, Sanders PW, Aban I, Love TE, Arnett $D$, et al. Isolated systolic hypertension and incident heart failure in older adults: a propensity-matched study. Hypertension.2009; 53: 458-465.

4. Iyer AS, Ahmed MI, Filippatos GS, Ekundayo OJ, Aban IB, Love TE, et al. Uncontrolled Hypertension and Increased Risk for Incident Heart Failure in Older Adults with Hypertension: Findings from a Propensity-Matched Prospective Population Study. J Am SocHypertens. 2010; 4 (1): 22-31.

5. Institute of Public health of Serbia "Dr Milan JovanovicBatut". Statistical yearbook of the Republic of Serbia 2015. Belgrade: Institute of Public health of Serbia, 2016. Available on: www.batut.org.rs/ download/publikacije/pub2015.

6. Institute of Public health of Serbia "Dr Milan JovanovicBatut". National health survey Serbia, 2013. Belgrade: Republic of Serbia Ministry of health, 2014. Available on: http://batut.org.rs/download/publikacije/IstrazivanjeZdravljaStanovnistvaRS2013.pdf

7. European Commission. European Health Interview Survey (EHIS wave 2) - Methodological manual. Luxembourg: Publications Office of the European Union, 2013.

8. Biorac N, Jakovljević M, Stefanović D, Perovic S , Janković S. Assessment of diabetes mellitus type 2 treatment costs in the Republic of Serbia.VojnosanitetskiPregled 2009; 6(4): 271-276.

9. Jakovljevic MB, Djordjevic N, Jurisevic M, Jankovic S. Evolution of the Serbian pharmaceutical market alongside socioeconomic transition. Expert Rev Pharmacoecon Outcomes Res. 2015;15(3): 521530.

10. Petrusic T, Jakovljevic M. Budget impact of publicly reimbursed prescription medicines in The Republic of Srpska. Front Public Health. 2015; 10(3): 213.

11. Everett B andZajacova A. Gender Differences in Hypertension and Hypertension Awareness Among Young Adults. BiodemographySoc Biol. 2015; 61(1): 1-17.

12. Choi EJ, Jekal Y, Kim S, Yoo JS, Kim HS, Oh EG, et al. Middle-aged women's awareness of cholesterol as a risk factor: results from a national survey of Korean Middle-aged Women's Health Awareness (KomWHA) study. Int J Nurs Stud. 2010;47(4):452460.

13. Go AS, Mozaffarian D, Roger VL, Benjamin EJ, Berry JD, Borden WB, et al. Heart disease and stroke statistics--2013 upYeste: a report from the American Heart Association. Circulation 2013;127:6-245.

14. Adebolu FA, Naidoo M. Blood pressure control amongst patients living with hypertension presenting to an urban district hospital outpatient clinic in Kwazulu-Natal. Afr J Prim Health Care Fam Med. 2014; 6(1): 6 .

15. Stokes GS. Management of hypertension in the elderly patient.ClinInterv Aging.2009; 4: 379-389.

16. Logan AG. Hypertension in Aging Patients. Expert Rev CardiovascTher. 2011; 9(1): 113-120.

17. Vitale C, Fini M, Speziale G, Chierchia S. Gender differences in the cardiovascular effects of sex hormones. FunYesmClinPharmacol. 2010; 24(6): 675-685.

18. Sandberg K, Ji H. Sex differences in primary hypertension. Biol Sex Differ. 2012;3(1):7.

19. Yu HT, Kim KJ, Bang WD, Oh CM, Jang JY, Cho $\mathrm{SS}$, et al. Genderbased differences in the management and prognosis of acute coronary syndrome in Korea. Yonsei Med J. 2011;52(4):562-568.

20. Folic $M$, Folic $N$, Varjacic $M$, Jakovljevic $M$ and Jankovic $S$. Antihypertensive drug therapy for hypertensive disorders in pregnancy. ActaMedicaMedianae 2008; 47(3): 65-72.

21. Riha J, Karabarinde A, Ssenyomo G, Allender $S$, Asiki G, Kamali A, et al. Urbanicity and lifestyle risk factors for cardiometabolic diseases in rural UganYes: a cross-sectional study. PLoS Med. 2014;11:e1001683.

22. Abdul-Razak S, Daher AM, Ramli AS, Ariffin F, Mazapuspavina MY, Ambigga KS, et al. Prevalence, awareness, treatment, control and socio demographic determinants of hypertension in Malaysian adults. BMC Public Health. 2016; 21(16): 351. 


\title{
Uticaj sociodemografskih faktora na upotrebu antihipertenzivnih lekova kod odraslih u Republici Srbiji: studija preseka
}

\author{
Nataša M. Mihailović ${ }^{1}$, Snežana M. Radovanovićc,3, Dragan V. Vasiljevićt, \\ Nela Ž. Donovićt,5, Svetlana R. Radevićs, Mihajlo B. Jakovljevićc \\ ${ }^{1}$ Centar za biostatistiku Instituta za javno zdravlje Kragujevac, Kragujevac, Srbija \\ ${ }^{2}$ Centar za socijalnu medicinu Instituta za javno zdravlje Kragujevac, Kragujevac, Srbija \\ ${ }^{3}$ Socijalna medicina, Fakultet medicinskih nauka Univerziteta u Kragujevcu, Kragujevac, Srbija \\ ${ }^{4}$ Centar za higijenu i humanu ekologiju Instituta za javno zdravlje Kragujevac, Kragujevac, Srbija \\ ${ }^{5}$ Higijena i ekologija, Fakultet medicinskih nauka Univerziteta u Kragujevcu, Kragujevac, Srbija \\ ${ }^{6}$ Zdravstvena ekonomija i Farmakoekonomija, Fakultet medicinskih nauka Univerziteta u Kragujevcu, \\ Kragujevac, Srbija
}

\section{KRATAK SADRŽAJ}

Uvod: Uprkos saznanju da imaju povišen krvni pritisak koji je lekovima moguće držati pod kontrolom, deo pacijenata ignoriše preporuke lekara i odbija lečenje. Cilj istraživanja bio je analiza uticaja socio-demografskih faktora na lečenje hipertenzije među odraslima u Srbiji.

Predmet i metode: U istraživanju su korišćeni podaci Nacionalnog istraživanja zdravlja stanovništva Republike Srbije, sprovedenog 2013. godine. Uzorak su činili ispitanici koji su imali dijagnostikovan povišen krvni pritisak, njih 5073. Zavisna varijabla u istraživanju bila je binarna (leči/ne leči hipertenziju), a nezavisne su bile socio-demografske karakteristike ispitanika. Uticaj socio-demografskih prediktora na lečenje povišenog krvnog pritiska ispitivana je logističkom regresijom.

Rezultati: Od ukupno 5073 dijagnostikovanih hipertoničara, 91,3\% njih leči povičen pritisak. Univarijantna analiza pokazuje da žene, stariji, srednje bogati, oni koji prate zdravstvene teme putem televizije, ali ne i preko interneta, koji su bili na stacionarnom lečenju u perthodnih 12 meseci, ili koristili usluge dnevne bolnice značajno češće leče hipertenziju. Rezultati logističke regresije pokazuju da su značajni prediktori u lečenju hipertenzije: starost, pol, materijalno stanje i praćenje zdravstvenih tema putem televizije i interneta. Najsnažniji prediktor je materijalno stanje. Srednje bogati ispitanici gotovo tri puta češće leče hipertenziju u poređenju sa najbogatijima $(\mathrm{OR}=2.94,95 \% \mathrm{Cl}=1.54-5.59)$. Statistički značajna razlika u lečenju nije zabeležena između najbogatijih i najsiromasnijih ( $p>0.05)$. Muškarci 1.5 češće leče hipertenziju u poređenju sa ženama $(\mathrm{OR}=1.54,95 \% \mathrm{Cl}=1.02-2.32)$. Ispitanici koji prate zdravstvene teme putem interneta 1.7 puta češće leče povišen krvni pritisak u poređenju sa ispitanicima koji iste ne prate $(\mathrm{OR}=1.72,95 \% \mathrm{Cl}=1.07-2.76)$.

Zaključak: Ispitivanje uticaja socio-demografskih karakteristika pacijenata na sve što značaju lečenja predstavlja važan korak u razvoju strategija lečenja obolelih.

Ključne reči: hipertenzija, antihipertenzivi, socio-demografski faktori 